\title{
From Polemic to Exegesis: The Ancient Philosophical Commentary
}

\author{
Han Baltussen \\ Classics, University of Adelaide
}

\begin{abstract}
Commentary was an important vehicle for philosophical debate in late antiquity. Its antecedents lie in the rise of rational argumentation, polemical rivalry, literacy, and the canonization of texts. This essay aims to give a historical and typological outline of philosophical exegesis in antiquity, from the earliest allegorizing readings of Homer to the full-blown "running commentary" in the Platonic tradition (fourth to sixth centuries CE). Running commentaries are mostly on authoritative thinkers such as Plato and Aristotle. Yet they are never mere scholarly enterprises but, rather, springboards for syncretistic clarification, elaboration, and creative interpretation. Two case studies (Galen 129-219 CE, Simplicius ca. 530 CE) will illustrate the range of exegetical tools available at the end of a long tradition in medical science and in reading Aristotle through Neoplatonic eyes, respectively.
\end{abstract}

\section{Exegesis and Commentary: The Birth of a Genre?}

Exegesis, broadly defined as the act of interpretation - the attempt to clarify an existing text, spoken or written - took a long time to reach maturity. The earliest attested evidence from ancient Greece illustrates how the practice of elucidating the meaning of an entire narrative or its supposedly

I would like to thank Peter Adamson (Philosophy Department, King's College London) and the readers of Poetics Today for helpful comments on the final drafts, the guest editor Jonathan Lavery for the opportunity to write on this topic and his support during the editorial process, and the Faculty of Humanities, Adelaide University, for financial support (URG 2003) of work on section 4.3 and Baltussen forthcoming c.

Poetics Today 28:2 (Summer 2007) DOI 10.1215/03335372-2006-022

(C) 2007 by Porter Institute for Poetics and Semiotics 
unclear parts grew almost organically. Gradually, innovations in method and strategy accumulated to form a rich textual tradition: first in religion (by so-called exêgêtai) and poetry, then in philosophical accounts of the cosmos, and finally in the metalanguage of commentators of late antiquity. By the end of this period, there was a rich trove of structurally complex texts whose guiding purpose was to clarify existing scientific, literary, and philosophical narratives.

In this essay, I shall sketch both the emergence and the development of exegesis, which culminated in the genre of commentary (its full-blown technical instantiation), by focusing on clear examples of writings in which one author engages with the writings of earlier authors in order to clarify the thoughts contained in them. Unhappily, even mature commentaries have recently been characterized as "secondary texts" (Sluiter 2000). I will argue that this label is problematic in so far as it is likely to create misconceptions about how we should understand the nature of philosophical commentary as one specialized form of exegesis. It is important not to understand "secondary" as "unimportant," "subservient," or "unoriginal." I hope to show that the commentary in late antiquity defies such facile descriptions. I will also argue that we will understand the mature form better if we first look at the stages leading up to formal commentary, in particular by paying attention to the role of polemic as a formative factor in the development of interpretive strategies. The linear progression presented here is imposed for the sake of exposition and clarity and should not be taken as an argument for linear evolution. Given its scope, this essay can only provide a selective and incomplete account as a first step toward a history of the ancient philosophical commentary.

My aim, then, is twofold: one, to offer a compact history of exegesis in Greco-Roman antiquity. This history will outline the relevant chronological progression, beginning with the incipient activities of exegesis and the preconditions for the interpretation of texts as an established practice, then elaborating on the mature, formal, and distinct genre of the running philosophical commentary. ${ }^{2}$ And, two, to provide a typological account which describes the evolving variants of commentary from its Presocratic roots to late ancient scholarly texts. On the basis of this combined historical and typological account, we should be well-placed to see the fluid and progressive interaction between form and content within the genre. The particular

1. From the perspective of interpretation "which takes control and . . remakes its object in the very act of its subservience," McCarty (2002: 363$)$ has declared the commentary "primary" in relation to the text commented on.

2. Space prevents me from dealing with ancient rabbinic exegesis/commentary on the Bible, with which there are interesting points of contact; see Levinson 2004. 
nature of the formal commentary as a responsive medium for philosophical engagement, in which one text interacts with another text in a relation that is driven by didactic and systematic motives, brings into focus how the notion of authority came to lie at the heart of the commentary tradition. The choice of a particular text as carrying an important philosophical message accords it special status and authority, which, as we shall see, can be both challenged and defended.

The emphasis on polemic and exegesis as central terms in this account (including my title) may need some justification. Unlike standard accounts, I aim to capture the dynamic nature of the tradition in referring to the full spectrum of formal and nonformal acts of interpretation; commentary is not a fixed entity through time. My preference for the generic term exegesis over commentary also serves as a measure against equivocation: commentary will be used in a more restricted sense, as a developed, formal version of exegesis. The modern understanding of "commentary" tends to evoke the practice of providing a sustained and comprehensive annotation to a text according to high standards of scholarly rigor. My more inclusive approach, as expressed by exegesis, also accommodates early interpretive activities not covered by commentary. But there is a more fundamental reason to avoid the modern notion of commentary for the material I want to discuss. Whereas in most cases a modern commentary tends to be an end in itself, producing a set of disparate notes to a text and lacking a unifying principle of its own (a "plot"), the ancient philosophical commentaries emerging after the first century BCE tend to serve a higher purpose (philosophical understanding and truth) by way of interpreting the thoughts of a scholar. This holds indisputably for the Platonic tradition, from its first observable example (anonymous commentary on Theaetetus, first century $\mathrm{BCE})$ to commentaries that were written as late as $700 \mathrm{CE}$.

Needless to say, this approach requires us to put aside the modern notion of commentary as a formal type of writing with the sole purpose of explicating another text from start to finish (cf. note 45), especially in light of the fact that a literate social context, in which written texts are central, was a fairly late development in ancient culture. ${ }^{3}$ Only a literate context could generate the requisite technical terminology, foster challenges to tradition and religious authority, and help unearth underlying assumptions in formerly oral reflexes. ${ }^{4}$ The development I present uses

3. Most (2005: 169) signals that the current view of scholarly commentary is changing: "Perhaps for the first time in a hundred generations, the commentary is no longer being taken for granted as self-evidently the noblest expression of the study of texts."

4. The increased awareness of traditional thought patterns is crucial to the rise of secondorder discourse. This position, further developed in this essay, emerges from inquiries into 
examples which are each meant to be representative of distinct stages. I will outline the earliest stage of emerging exegetical activity and then go on to discuss a few important steps toward the development of philosophical exegesis of a more scholarly nature. Two case studies, one of the great physician and philosopher Galen (129-219 CE), the other of the late Platonist Simplicius (ca. 530 CE), will illustrate the levels of sophistication evident in later examples of the formal ancient philosophical commentary. The result should be a historical and typological narrative which describes and analyzes an increasingly self-conscious activity in its evolution from humble beginnings to complex maturity. This promises to give a unique insight into the first attempts at exegesis and the formative stages of its development.

\section{The Nature and Origin of Exegesis}

The act of interpretation is as old as language itself and an essential part of communication. Understanding the meaning of words, whether spoken or written, is of perennial importance. Language is used to make sense of the world, as a basic human activity for finding meaning in and sharing our experiences. ${ }^{5}$ Stories about the gods and their role in the cosmos clearly served this purpose for the earliest civilizations. At some point, when the level of sophistication in our modes of expression and communication had increased far beyond the needs of mundane and practical usage, texts became more complex, and so, as a corollary, did our strategies of interpretation.

Semantic analysis, in order to make sense of words, is not much different from making sense of the world, though clearly it is more of a secondorder activity, words clarifying words. Three antecedent conditions were important for the rise of this second-order operation: a body of "literary" works (oral or written), a community with a shared "literature," and an understanding of the difference between literal meaning versus nonliteral meaning. The oscillation between these factors is a constant from the earliest cases of "literary criticism." Allegorization of Homer's epics can be dated to the sixth century BCE, when the first philosophical interpretations were emerging together with some of the playful literary responses to the Homeric language found in the early lyrical poets, such as Archilochus and Pindar (Nagy 1990, Obbink 2003). Early literary and philosophical engagement with the central text of preliterate Greek culture is discernible

the rise of literacy (e.g., Havelock 1982 [1966]; Ong 1982; Thomas 1992) and the first known philosophical interpretations of religious texts (Janko 2002-3; Obbink 2003, Betegh 2004). 5. For a similar point see Yunis 2003: 189 . 
in small traces, providing evidence of a surge in exegetical activities in the late archaic and early classical period (ca. 750-45o BCE).

As literacy was the privilege of very few people in a predominantly oral world, advanced exegetical activities were closely connected to welleducated aristocrats active in public life (politics and religion) and are likely to have arisen in making sense of laws, riddles, and oracles (Robb 1983). These involved the earliest "acts of exegesis" in ancient Greece. ${ }^{6}$ For instance, oracles from Delphi, famous for their ambiguity, represented the shrewdness of politically informed priests, whose advice could topple empires and destroy cities. "Disambiguating" these riddles thus became a major part of decision making, and the greater one's aptitude at distinguishing various meanings, the better one would be at producing possible interpretations. In the Derveni papyrus, which offers an allegorical interpretation of an Orphic religious poem (Betegh 2004), ${ }^{7}$ Orpheus is said to offer "important things in riddles" (expressed in the word hierologeitai, literally "tell a holy tale"; see Janko 2002-3: 5). Secrecy befits the sacred.

But the language of everyday life became inadequate to express the supposed deeper meaning of Hesiod's didactic poetry or Homer's epics. Homer exegetes ("Homeridae") appear quite early on, claiming him as their ancestor as early as the sixth century BCE. The ironic portrayal of a rhapsode in Plato's dialogue Ion (fourth century) gives us some sense of the style and approach of these Homeric "experts," even if the selfpresentation of the protagonist (Ion 530c, hermêneus ["interpreter"]) and his confidence in knowing what Homer means must not be taken at face value. The Homeric "text" sung by the bards could attract interpreters in different ways: the formulaic style gave bards some freedom in composition, allowing for individual differences in presentation of events, characters, and emotions - the first signs of reinterpreting a text creatively. It has even been suggested (Zwierlein 2002: 89, after Pfeiffer 1978) that Homer practiced "self-interpretation": for instance, by providing etymology to clarify names, a suggestion already made by the Stoic Zeno in the third century BCE (cf. below, section 3).

Only when the text was written down (750/70o BCE?) would new problems arise, since multiple versions of a text could now undermine certainty about the content or raise questions about which is the "correct" version. The fragmentary evidence on allegorical and cosmological interpretations of Homer dates to the sixth and fifth centuries BCE, starting, so far

6. On oracles and bards see, e.g., McLeod 1961, Fontenrose 1978 and Rosenberger 2001; on riddles, Forster 1945 and Humphreys 1996. By the time of Thucydides, a change in attitude is discernible in his cynical view of oracles (Peloponnesian War V.103; Dover 1988: 72).

7. A full-scale analysis of the Derveni papyrus (PDerv) is now available in Betegh 2005. 
as we know, with Theagenes of Rhegium (ca. 525 BCE), Metrodorus of Lampsacus, and Stesimbrotus of Thasos. ${ }^{8}$ All three are reported to have used etymologies and to have offered allegorical interpretations of myths. ${ }^{9}$ Metrodorus, a pupil of the Presocratic Anaxagoras (ca. 430 BCE), claims the presence of a world/body analogy in Homer's epic while "reading" the gods as symbols of body parts (Califf 2003). Some of these early techniques are fanciful allegorical readings with attempts to see heroes as parts of the universe. Others are mythological with some etymology thrown in (Richardson 1975), while Stesimbrotus also shows an interest in symbolism and apparently wrote a work entitled Exegesis of Pythagorean Symbols (fr. 58C6 Diels-Kranz $\left.{ }^{10}\right)$. In the repertoire of these early "exegetes," particularly striking features are the distinction of a word's different meanings, the assumption that a text has a hidden meaning (huponoia, "under-meaning"; Richardson 1975: 66-67), and a general concern for the plausibility of how the text represents the world. As we shall see, these features will promote a more coherent strategy by the early fifth century BCE, in Plato's Protagoras.

The rise of this new outlook must be sought in broad cultural developments. In the seventh and sixth centuries BCE, a new perspective on the world arose from the cultural ferment of the trading centers in Asia Minor (Miletus, Colophon, Ephesus). There, previous certainties were questioned, alternatives to existing customs considered, and new forms of discourse invented, all of which would drive philosophical analysis of the world and its components (Most 1999a). The natural philosophers began to explain the world in a way radically different from Homer's mythical accounts. Refuting opponents meant offering alternative causes or material constituents. Fragmentary Presocratic texts show imaginative individuals proposing certain primary stuffs as the origin of everything (Thales: water; Anaximenes: air; Heraclitus: fire). Before long, a competitive spirit began to encourage philosophers to probe the linguistic expression of their rivals' positions, thus also exploring an interpretive and argumentative route in trying to assess whose explanation was superior (Cherniss 1977). Such interaction signals the new role of polemic in the interpretation of both

8. Richardson $(1975,1980,1992)$ has usefully outlined some of the evidence we have for the early engagement with the Homeric poems; see also note 9.

9. The evidence for Theagenes is found in a scholion on the Iliad 20,67 = fr. 8,2 DK (Algra 2001: 562n1); see also Yunis 2003: 193 on Plato's Ion, in which Ion claims, remarkably, to be better than both Metrodorus and Stesimbrotus at interpreting Homer. Clearly these two were household names in Athens with regard to Homer exegesis.

10. Diels-Kranz (hereafter DK) refers to the edition of the fragments of Presocratic philosophers and some contemporary intellectuals (ca. 700-40o BCE) in the 1989 reprint of the 6th edition in Berlin in $195^{2}$. 
the world and the word. For instance, Xenophanes famously criticized the Homeric gods (fragments $\mathrm{B}_{1} 4^{-16} \mathrm{DK}$ ) on the good grounds that an anthropomorphic depiction saddled them with human features (jealousy, greed, etc.) unbefitting divine beings. No doubt Xenophanes' awareness of his audience and of the value of persuasive rhetoric also play their role here, since his polemic may aim at both refutation and persuasion.

Among the necessary conditions for sophisticated textual analysis and interpretation, the most important was the gradual change from an oral to a more literate society (Havelock 1963, Thomas 1992). The transition shows most clearly in the rise of prose texts, which are an immediate result of writing; oral cultures prefer poetic forms, in part for their mnemonic value. Developments in rhetoric led to more sophisticated exegetical strategies, including the shaping and sharpening of the tools of exegesis: interest in argumentative patterns, in technical terminology, in techniques for structuring prose, and in grammar all developed from this cultural transformation. Polemic enters from the earliest philosophical testimonia on Parmenides and Empedocles, Xenophanes, Heraclitus, Democritus. Text (rhêton) and subtext (dianoia/huponoia) became lexical reflexes of physical phenomena and their deeper meaning: "the appearances are a glimpse of the obscure" is a slogan attributed to several Presocratics, in particular Anaxagoras (fr. B21a DK) and Democritus (fr. B117 DK).

Different approaches to interpretation can be identified among the Presocratics, ranging from more systematic explanations of earlier philosophers to highly polemical refutations. Empedocles (ca. 500 BCE) is clearly trying to take up the challenge of Parmenides' arguments against the possibility of motion, but he goes far beyond a polemical refutation by giving a comprehensive and systematic explanation of the physical world and its genesis. Theagenes' allegorizing interpretation of Homer was in part a defense against the moralizing criticism leveled at the poet by Xenophanes (Janko 2002-3: 7-8). Heraclitus wanted to counter some of the misguided ideas of his predecessors that "knowing a lot of things" (polymathia [fr. 40 DK]) would amount to understanding or intelligence (noos). He draws an interesting contrast between the amount of information (polymathia, a quantitative notion) and the right kind of interpretation (noos, a qualitative notion). Such critical assessments clearly illustrate the competitive nature of philosophical debate and presuppose a shared sense of purpose: to give an explanatory account of the world but (unlike Hesiod or Homer) a rational one.

These cases show how, within 250 years of its introduction, writing became the vehicle of elaborate theoretical speculation, even if it came initially in the traditional guise of poetry (Parmenides, Empedocles, and 
Xenophanes use Homeric hexameter). Such "cultural hybrids," presenting oral thought patterns in prose or rational thought in poetry (Russo 1997), are the hallmark of the transitional phase of this period of Greek science and cosmology (Havelock 1982, Ong 1982).

Prose writings in oral style began to win ground with Pherecydes of Syros (ca. 540 BCE) and Heraclitus (ca. 50o BCE). The latter, nicknamed the "riddler" by Timon of Phlius (Diogenes Laertius 9.6), deliberately used an oracular, enigmatic style (West 1971) - as in the aphoristic "the way up and down is one and the same" (fr. 6o DK). He thus provoked his audience to inquire further, by a pedagogical technique that would be much refined by Plato in his dialogues. Here the inquiry becomes a continuous dialogue, or rather trialogue, implicating the reader as interpreter. Interpretation becomes a creative activity in the form of exegesis, which can take the form of rephrasing, explicating, and rejecting the views discussed. Clearly these early philosophical styles are part of a transitional stage and primarily first-order clarifications: the polemical, second-order aspect is reactive and negative in that it aims to counter an opponent's view while merely implying that the critic was right, because the opponent had been "proven" wrong. To build a positive case requires a further effort (e.g., a cosmogony, an evolutionary story, or a teleology). ${ }^{11}$

It is in the fifth century BCE that clear evidence for a second-order discourse (in the sense of a text talking about another text) is found in philosophical circles. This is a period when different strands from rhetoric, religion, and philosophical discourse contribute to this new form of "commenting on" other people's views as a self-conscious and self-contained activity: a written text was viewed as objectivized thought, lending a more fixed character to words and ideas which had been fluid and expressed in various ways when transmitted orally (Yunis 2003). To trace this new trend, we need only look at the Sophists, Plato, and Aristotle as the clearest cases (see also the next section). Word games and more meticulous analyses, assisted by writing, raised awareness of the processes of thought and argumentation, leading to linguistic stability and semantic differentiation. For example, terms for types of writing proliferate, and soon distinctions between comments (hypomnêmata) and preparatory notes (hypomnêmatikon) helped describe the compositional stages of interpretive works (Dorandi 1991). In the relatively short period of one hundred years $(480-380 \mathrm{BCE})$,

11. Depending on the survival of the work, we can see that some or all of these components are present. For a fascinating analysis of the ways in which early Greek philosophy was informed by existing literary modes of composition and presentation, see also Most (1999b: 342), who speaks of "implicit poetics of early Greek literature" and "the context of expectations." 
this trend helped crystallize certain existing techniques in rhetoric (Mansfeld 1986) and in emerging philosophical argumentation (Nehamas 1990) into what was to become philosophical commentary: it involved the methodical evaluative scrutiny of existing philosophical views with the purpose of pushing forward the search for the truth. Thus, polemic progressed and was absorbed into systematic dialectic. Formalization was the next logical step.

\section{From Exegesis to Commentary}

The first ancient philosophical commentary is commonly placed in the first century BCE/CE, but a quick review of the diverse opinions on the subject shows that there exists in fact little agreement on this issue. ${ }^{12}$ The discussion suffers from incomplete evidence and a lack of clarity in definition (e.g., comments on parts of works are conflated with running commentary), while the incipient nature of the genre is usually ignored. But the crucial issue for this investigation-how various influences informed the evolution of philosophical interpretation at different stages - requires a more dynamic account to show that the strategies and tools used reflect the ongoing change and development of exegesis. Let us review some important evidence.

The fifth century BCE starts and ends with political upheaval in Athens. ${ }^{13}$ Greek cultural identity as a unifying notion owed much to the wars against the common Persian enemy but even more to Homer and the rise of influential intellectual figures who developed classical drama (Aeschylus, Sophocles, Euripides), rhetoric (Gorgias), cultural history, and linguistics (Protagoras, Prodicus) within the newly established urban environment. From the grand cosmic themes of fate and justice to more practical matters of litigation, the Athenians - whether native or adopted-rapidly honed their argumentative skills, culminating in rhetorical masterpieces of the courts and the agora. Gorgias's Encomium of Helen (ca. 414 BCE) is a good example of sophistic reasoning: it is an unorthodox and irrev-

12. Should we agree with John Dillon (1996 [1977]: 437), who has suggested that "it is only in the generation of Eudorus [first century BCE] that the tradition of formal commentary on both Plato and Aristotle seems to begin"? (my emphasis). His comment does not sit well with another, in which he states (ibid. 43): "Crantor [third century BCE] who wrote the first formal commentary as a Platonist on a work of Plato." Other views are more implicit about the supposed inauguration of commentary as a genre, ranging from the third century BCE (Aristotle's immediate successors) to the first century BCE.

13. The so-called "golden age" under Pericles $(461-429$ BCE) came after the wars against Persia $\left(49^{2}-489,480 \mathrm{BCE}\right)$ and before the collapse of Athenian power in the war against Sparta $\left(43^{-}-404\right.$ BCE). 
erent display of rhetorical skill, arguing that Helen was not to blame for choosing to go to Troy with Paris (Wardy 1996). Persuasion is a major aim here, and it operates through the subtle use of language, particularly of grammatical and argumentative structures which help to forge the technical apparatus for the second-order activity of explaining texts: we find metalinguistic comments on syntax and semantics, polemical strategies for refuting an argument (e.g., reductio ad absurdum), and shrewd, "mindbending" tactics. ${ }^{14}$

In spite of his strong rejection of sophistic morals and style, Plato stands at the crossroads of oral and literate forms of expression. ${ }^{15}$ Seen within this broader intellectual context, his dialogues appear at a time when certain exegetical tactics were already well established, but they do not yet belong to a self-conscious, scholarly enterprise with formal rules. As Glen Most (2005: 169) aptly describes the process, "Commentators have always theorized . . . but for thousands of years this theorization tended to take the form of tacit knowledge, oral report, and personal anecdote." Plato's awareness of the growing use of writing (e.g., Phaedrus 274b-276a; see Havelock 1963), his suspicions of its effects on traditional approaches to poetry and education, and his reservations about the philosophical use of writing are the clearest indications of how the new age of literacy started to influence the intellectual circles of Athens. But Plato is mostly concerned with philosophical debate, and the use of writing was still rather restricted, slowly (but never fully) replacing traditional oral modes of expressing thought. ${ }^{16}$ By giving pride of place to oral teaching, Plato is in fact fighting a rearguard battle against the advance of the use of writing, which could no longer be stopped.

The discussion of a poem by Simonides in Plato's Protagoras 339a-348c is a prime example of emerging commentary, as it incorporates exegetical tools found in the Homerists and the Sophists. The idea that in this dialogue we can glimpse a developed stage of formal exegesis is not entirely new, but comments to that effect are mostly limited to passing remarks. ${ }^{17}$

14. For a lucid discussion of the influence of rhetoric on hermeneutics in the Roman period, see Eden 1997: chaps. 1-2. On the psychagogic powers of Gorgias, the classic treatment is Segal 1962.

15. Some see signs of transition already among the Presocratics (e.g., Havelock 1982 [1966]; Robb 1983). For some important critical notes on the Presocratic role in the growth of literacy, see Ferrari 1984.

16. By bringing in the oral/written opposition, I have given one reason for taking Plato as an example and a starting point for the rise of formal commentary. A further reason is that he describes the interpretative process in detail, reflecting on topic, method, and the claims made by the interpreter.

17. See, e.g., Richardson 1975, Scodel 1986, Carson 1992, Eden 1997, Hussey 1999. This paragraph summarizes Baltussen 2004. 
The Simonides episode is one of several in which we see Plato adopting and discussing the practice of clarifying a text in a way that must have had a well-established role in the education of wealthy Athenians: when Socrates offers to show Protagoras his ability at "interpreting" poetry (Protagoras $342 \mathrm{a} 1-2)$, he picks up on an earlier remark from Protagoras that reading poetry is a true gentleman's activity (339a). ${ }^{18}$ Socrates claims to know the author's intention (boulêsis), uses grammatical arguments to prove points, and proposes different ways of illustrating the hidden meaning (dianoia; $341 \mathrm{c} 8,347 \mathrm{a} 4)$ of the poem, such as postulating an unusual meaning for a word (341b1-2). Moreover, the interpretation also includes two prototypes of hermeneutical principles concerning the importance of consistency (341e1-2, what became known as the "Homer from Homer" principle in later times) and the assumption that one can attribute an overall purpose to a poem rather than simply interpret single words or phrases. ${ }^{19}$ But Socrates abruptly turns away from this activity, saying it is not what they should be doing if and when they want to engage in testing truth and their own ideas instead of those of others $\left(347^{-}-348 \mathrm{a}\right)$. Thus, the seeds of the commentary tradition were already sown in the pre-Platonic literary tradition, and the Protagoras passage can be used as a window on the past, as a display of sophistic methods based on an earlier tradition. Even if we allow for an element of parody in Plato's representation of these practices, it had to contain realistic features to be plausible and credible for his audience. ${ }^{20}$

With the possible exception of the Derveni papyrus (see section 2), the first clear evidence for a philosophical work commenting extensively on another text is post-Platonic. ${ }^{21}$ Crantor, a pupil of Plato in the early Academy (ca. $35^{\circ}$ BCE), is usually mentioned as the "first commentator" on Plato's cosmological account the Timaeus (Proclus, On the Timaeus I, p. 76, 2.277,8; Diehl 1903-6). The label exêgêtês, previously used of religious interpreters, is here applied to a natural philosopher. Given the late date of our source (Proclus lived ca. 410-485 CE), the use of exêgêtês requires caution: to translate it as "commentator" might be misleading. Crantor probably wrote only short comments on selected passages (not a full running

18. See also Ford 1994, which offers a persuasive argument for Plato's awareness of the special requirements for interpreting fragmentary texts.

19. The seminal paper on the Homerum ex Homero principle is Schäublin 1977; cf. recent observations in Mansfeld 1994, Sluiter 2000, Baltussen 2004. See also section 4.2 of this essay.

20. See a more elaborate argument for this in Baltussen 2004; cf. Yunis 2003, Kahn 2003.

21. The contrast drawn here between religious and philosophical discourse should not be taken as a strict opposition. I merely want to highlight the dominant factor which sets the Derveni papyrus apart from the Anon. In what follows, it will become clear that the religious aspect never ceases to play a role. 
commentary ${ }^{22}$ ), and given Proclus's tendency to merge the religious and the philosophical, the term may have a double reference, with a reminder of its original use..$^{23}$

Polemics continued to play a significant role in philosophy after Plato. Of course, polemic and refutation are often biased forms of interpretation, but they will nonetheless be based on an interpretive act (or the presumption of such an act), going some way toward sharpening the mind and method of those who engage in it. ${ }^{24}$ Therefore, these different early forays into exegesis, no matter how embryonic in character, led to a considerable rise in works with an interpretive objective directed at refutation and response. The Protagoras passage thus shows that polemic and exegesis contributed to the development of a more sophisticated methodology in the interpretation of texts.

As a result, philosophy also became a scholarly enterprise in the fourth century BCE. Aristotle wrote a work entitled Homeric Problems while also composing responses to or comments on individual thinkers and schools (e.g., Diogenes Laertius [= D.L.] 5.88 Response to Democritus's Exegeses, 1 book). His colleague and successor Theophrastus probably wrote extensive polemical notes assembled in a collection of Objections (D.L. 5.4349). ${ }^{25}$ In Plato's Academy, Arcesilaus had a reputation as a scholarly man (D.L. 4.30 "lover of letters," philogrammatos), while Crantor is said to have composed "notebooks" (hypomnêmata [D.L. 3.24]). Epicureans are also mentioned as involved in the learned activity of writing critical works or summaries of the ideas of others. ${ }^{26}$ The Stoics were known to interpret

22. See Runia 1986: 47, 53. Historical and literary output at the time supports the claim that full-blown running commentaries do not yet exist: "commentary on the Royal Diary of Alexander" [ca. 335 BCE] (Hammond 1987); "the first attested commentary on a text, Aristophanes' Plutus, [was] by Eratosthenes' pupil Euphormius" [ca. third through second centuries BCE] (Wilson 1969: 370, ignoring the Derveni papyrus, published in rudimentary form in 1967); "the first commentary on a prose author: Aristarchus's commentary on Herodotus" [second century BCE] (ibid.: 371). Cf. note 31.

23. Possibly an etymologizing comment. For Proclus's fusing of religion and philosophy, see especially van den Berg 2001.

24. There were no rules of fair play in debate (Long 1992: 50). The seminal article on polemic in this context is Owen 1983; see also Baltussen 2003.

25. Confirmed by another passage of the Platonic commentator Taurus, quoted in Philoponus, Against Proclus vi 8 (145.20-4 Rabe 1963 [1899]) = Theophrastus fr. 241c FHSG. Theophrastus's On Sense Perception also illustrates the point (Baltussen 2000).

26. Epicurus is said to be "highly educated (philographôtatos) and surpassing all in the quantity of books" and "summary of the books against the natural philosophers" (D.L. X.26). In an exegetical treatise preserved on a papyrus from Herculaneum (PHerc. 1012), Demetrius of Laconia, a well-known Epicurean (ca. 100 BCE), discussed difficult passages (cruces) in important works by Epicurus (Sedley 1998: 70). 
poetry by Hesiod (Algra 2001), Homer (Long 1992), and many others. Zeno wrote refutations (elenchoi [D.L. 7.4]) and Kleanthes explanations of Heraclitus (Exegeses of Heraclitus, 4 books [D.L. 7.174] ${ }^{27}$ ). Beyond these titles, the evidence is fragmentary and limited, yet they are a clear indication of the lively activity of interpreting the views of others in the fourth century BCE.

A more advanced stage can be seen in Peripatetic discussions of their philosophical predecessors. ${ }^{28}$ Aristotle's approach in preliminary passages of his Metaphysics A, On the Soul A, and Physics A, criticizing anterior views on the subject, seems to represent early attempts at interpreting the ideas of others within the systematic context of his own argument. His immediate successors (after $322 \mathrm{BCE}$ ) were left with the task of keeping a school going that needed to cover an unprecedented range of research activities and build on a wide body of knowledge. ${ }^{29}$ Consolidation was only one of the strategies, and the individual responses to the work of the school's founder included critical corrections as well as expansive supplementation (Fazzo 2004). Theophrastus's discussion of the Presocratics and Plato in his On Sense Perception also involves textual exegesis with clear signs that he dealt with a written original (Baltussen 200o). By now, the discussion of the intended meanings of his master's works and the need for subtle corrective maneuvres, however, signal a new problem: would challenging the corpus threaten its authority - and thus impede its canonization? As in Plato's Academy, subsequent generations had to consider the unity of the founder's thought. This created a tension between philosophical creativity and the notion of authority.

So, some three centuries after the first written version of Homer's epics and 150 years after the first major allegorical readings of these epics, philosophy is seen to enter the arena of textual interpretation, with written texts as a basis for study and clarification. Fusing literary with philosophical methods, Plato and Aristotle offer critical discussions of increasing subtlety and sophistication, appropriating what they considered useful and rejecting what they considered misguided or wrong. The tradition was being constructed in the light of their own achievements, casting their predecessors in the role of "mumbling precursors" to their own well-formulated ideas (Aristotle Metaphysics A.7, 988a22-24; 993a15). One generation later,

27. Gf. D.L. 7.178 on Sphaerus and D.L. 7.187 on Chrysippus.

28. See Baltussen 2000 with further references. For Aristotle's influence on Alexandrian scholarship (traceable from his Poetics and Homeric Problems), see Richardson 1993.

29. Continuation of the school was not certain: "Aristotle died in Chalcis . . . his school was in abeyance and his will gives no hint that he expected it to survive" (Gottschalk 2002: 26). 
the Stoics pushed the appropriation of past achievements even further: for instance, when they try to make the Presocratic Heraclitus (ca. 50o BCE) "fit the mold" of Stoic natural philosophy or when they declare Homer himself to be an allegorist (Long 1992). Such a method of fitting a square peg into a round hole-from now on a standard (though not always consciously applied) trick of the trade-resulted from the attempt to construe a worldview which could be regarded as a continuation of traditional Greek theological concepts. Even Homer exegesis would continue to play a part in the exegetical tradition up to the late Platonist commentators (Lamberton and Keaney 1992).

Clearly, then, there was considerable exegetical activity long before the anonymous Commentary on Plato's Theaetetus (referred to also as Anon.) appeared. ${ }^{30}$ Only a developmental account can use evidence from the fully developed form of commentary to infer anything about the character of earlier examples. No doubt Anon. is our first extant example of a formal commentary in the tradition of Plato's Academy (but see note 31), which lasted with some interruptions into the sixth century CE. This commentary uses basic techniques of clarifying words and phrases (with short tags as lemmata). From the surviving material, it can be inferred that it also aims at a comprehensive interpretation of the dialogue (skopos), including the prologues as symbolic representations of the characters. In other words, the work presents a continuation of the Platonic style of exegesis that we saw in statu nascendi in the Protagoras, itself evidence of both established practices and innovative moves.

In addition, a new dynamic arises with Anon. While the early instances of exegesis were either compositional (Homeric bards), oppositional (Presocratic polemic), or selective (Crantor), the anonymous Commentary on Plato's Theaetetus is the earliest extant case of a "running commentary" defending the Platonic position: a case of apologetics, mounted by a "convert," as it happens. Additional elements in the exegesis, however, also show the commentator to be a product of his time: his syncretism is evident in the Stoic and Peripatetic notions that merge with the Platonist perspective (Sedley 1997). He assumes a variety of outlooks, some of which may exert a subconscious influence on his style or his thought, because they were in circulation as the coin of contemporary philosophical currency. Yet in spite of its syncretism, the intention of this commentary (regardless of whether

30. Although the date for this work is disputed, it is generally assumed to be from the first century BCE or CE. A modern edition of the papyrus is in Bastianini and Sedley 1995. Its importance for the early history of philosophical exegesis has been emphasized by Tarrant 1993 and Sedley 1997. 
we judge it to be successful) is to offer a genuine Platonist interpretation. By now, the central text had gained so much authority that it could no longer be challenged-at least, not openly. The philosophical canon had arrived. ${ }^{31}$

\section{Running Commentary: $100-700$ CE}

\subsection{Aristotelians and Platonists in Late Antiquity}

After the anonymous Commentary, the first clear examples of the running commentary occur in the first and second centuries CE, such as those written by the Aristotelians Aspasius and Alexander of Aphrodisias (Hadot 2002a: 184) and by the Platonist Galen. Platonism would be dominant for the next four hundred years. Starting with Plotinus (ca. 210-275 GE), a new curriculum for would-be Platonists was designed and then developed further by Plotinus's pupil and biographer Porphyry, marking a new stage in the history of Greek philosophy (Sorabji 1990: $5^{-10}$ ). Again we find ourselves in an educational context, where direct teacher/pupil interaction remained crucial, but with a surprising twist: instead of upholding a sharp contrast between Plato and Aristotle, the Platonists started using Aristotle's work as the introduction to Plato's thought, and commentary on both authors became the preferred mode of education. As Richard Sorabji (ibid.: 5) puts it, "Not for the only time in the history of philosophy . . . a perfectly crazy position (harmony) proved philosophically fruitful. To establish the harmony of Plato and Aristotle, philosophers had to think up new ideas and the result was an amalgam different from either of the two original philosophies." Lloyd Gerson (2005: 270) clarifies why this was possible: "Platonists, for the most part, did not regard Aristotle as an antiPlatonist." 32 A new Platonism was born.

Despite a revived interest in Neoplatonism during the Renaissance, ${ }^{33}$ proper appreciation of this school of thought did not come until the twentieth century. The first and only modern edition of the Platonist commen-

31. Earlier Platonists obviously commented on his ideas (Dillon 1996 [1977], Tarrant 2000), but the earliest successors (Speusippus, Xenocrates) are still engaged in establishing the authoritative Platonic text, or in other words, what it is that might become the canon. According to Obbink (2003: 179), the earliest extant "commentary" on Plato is that on the Phaedo from the third century BCE. Plato's and Plotinus's works are the only ones to survive complete. 32. Gerson (ibid.: 271) also rightly emphasizes that "to be in harmony" "must be sharply distinguished from the view, held by no one in antiquity, that the philosophy of Aristotle was identical with the philosophy of Plato."

33. The translations and discussions of Marsilio Ficino (1433-99) did much to bring (Neo)platonism to the attention of the West and to counterbalance the dominance of Aristotelianism (see Schmitt et al. 1988). 
taries on Aristotle was published in the late nineteenth and early twentieth centuries under the general editorship of Hermann Diels on behalf of the Berlin Academy of Sciences. Diels's realization that some of these long works could actually be useful for other areas (Presocratic philosophy in particular) contributed to the production of some twenty-five fat volumes (about fifteen thousand pages) between 1887 and 1910. The edition includes commentaries on Aristotle's Physics, Metaphysics, and Ethics by the Aristotelian Alexander of Aphrodisias (ca. 200 CE) and by the Platonists Simplicius (ca. $530 \mathrm{CE}$ ), Philoponus (ca. $530 \mathrm{CE}$ ), Olympiodorus (ca. 650 CE), and others. But Diels's objective to mine these texts for precious fragments (a kind of antiquarianism which has gone out of fashion) already betrays his skewed interest in this corpus.

The edition's title emphatically announces the works as Greek commentaries on Aristotle (Commentaria in Aristotelem Graeca). This label contributed further to the identification and (we might say now) stigmatization of these works as derivative in form and a confused type of Platonism in doctrine. The latter judgment, based on commentaries from the fifth and sixth centuries CE, had been labeled "Neuplatonismus" (Neoplatonism) by the eighteenth-century encylopedists, who were anxious to pigeonhole these works. Of course, anything receiving the prefix "neo" is presumed to be of lesser value than whatever it is qualifying. ${ }^{34}$ Accordingly, these works were seen as secondary at best, while more severe assessments would regard them as parasitic. Such a view presumes a heavy-handed preference for the classical (Plato being "contaminated" by, or drowned in, syncretistic scholasticism) and places a rather modern, but misguided, emphasis on originality as the single most important criterion for philosophical discourse. This post-Romantic and one-sided view of the late Platonists has come under attack more recently; there are sufficient reasons to consider the late commentaries as distinct, creative, and sometimes even original pieces of writing (Sorabji 1987, 1990)..$^{35}$

In this section of the essay, two elements of this renewed study of late commentaries will be highlighted: the scientific (medical) commentary (section 4.2) and the late Platonist commentaries on Aristotle (section 4.3). Both types deserve more elaborate treatment, but my aim here is to assess briefly how the didactic motive behind them may have helped or hindered their exegetical mission.

34. See Hager 1983 on the origin and meaning of the term.

35. This seemingly radical shift has had to overcome ingrained views on the importance of the "classical" period. Renewed interest in Hellenistic philosophy in the 1970s and 1980s helped to break the dominant fascination with the classical period in modern scholarship. 


\subsection{Scientific Commentary: Galen}

The importance of the philosopher-doctor Galen (129-219 CE) in the development of commentary has long been underrated. Recent appreciation of his methodology and style has come with the reediting of his works ${ }^{36}$ and the renewed interest in ancient science and medicine. ${ }^{37}$ Galen adds a further dimension to commentary, because his work is shaped by his scientific outlook, his intelligence, and his keen sense of self-promotion (von Staden 1997). A Platonist in his broader outlook, he also adhered to Aristotelian science (as he understood it) with an emphasis on language, logic, and methodological rigor. But his focus was medicine and Hippocrates his hero. His commentaries on the Hippocratic Corpus (eighteen attested) are of immense value for studying the philological and exegetical development of the genre (Mansfeld 1994; Sluiter 1995; von Staden 2002).

His contributions fall under two headings: (a) as a scientific author, his methodology is characterized by respect for both logic and empirical evidence; (b) as an author living in the second century CE, he is heavily influenced by the so-called Second Sophistic, when a revival of classical Greek culture occurred. ${ }^{38}$ His presentation of arguments is thus scientifically thorough and rhetorically sophisticated, but as has been shown more recently, his public demonstrations of anatomical experiments also play a significant role (von Staden 1997).

For our purposes, it is important to understand his strategy in interpreting Hippocratic medicine. What are his presuppositions? What kind of issues does he consider important? How does he construct solutions to exegetical problems? Are there any patterns in his problem-solving method? Galen imposed upon himself a set of values which were to cause quite a few problems for his interpretive approach. For one thing, as a card-carrying Hippocratic, he would insist that Hippocrates was almost always right. Obviously, such a position would force him to make some unusual exegetical moves - for instance, to explain inconsistencies between the heteroge-

36. The standard edition of Kühn (1821-33) is slowly being replaced by modern editions, including CMG = Corpus Medicorum Graecorum (Berlin: Akademie-Verlag), but often we must still rely on Kühn.

37. The neglect of Galen is part of a broader trend: standard overviews of ancient scholarship (e.g., Pfeiffer 1978 [1968]) often focus on the literary evidence and tend to neglect philosophical and scientific writing. The pioneering article by Johannes Geffcken, "Zur Entstehung und zum Wesen des Griechischen Wissenschaftlichen Kommentars” (1932), has never received the follow-up for which its author may have hoped. Work is now underway to redress that imbalance.

38. The most informed analyses of Galen's method are found in von Staden 1995, 1997, 2002 (which I follow here) and Hankinson 1991, 1998. On the Second Sophistic see Anderson 1993, Whitmarsh 2005. 
neous works of the Hippocratic corpus or to clarify problematic passages. Galen may be trying to deal with such sources of "embarrassment" when he is seen to explain away textual problems in different ways (Sluiter 1995). He seems too dogmatic in his defense of Hippocrates, but again it shows how the canonization of an author lies at the heart of a commentator's motivation. In addition, his allegiance to both Plato and Aristotle only creates further difficulties on issues where these authors disagree (Barnes 1992; Baltussen forthcoming a). His eclectic education led him to take a syncretistic approach, but with it came the need to iron out clashes arising from three distinct systems of thought.

Galen's views on exegesis may have been shaped by discipline-specific examples, such as his teacher Pelops, who wrote private commentaries on Hippocrates. ${ }^{39}$ But he was also aware of broader principles of exegesis due to his familiarity with the "classics" and their reception. Clarity and clarification are his prime concern (On Hippocrates' On Fractures xviiiB, 318-19; Kühn: 1821-33):

Before I begin the detailed interpretation, it is worth saying in general about any interpretation that its purpose is to render clear what is unclear in the text itself. To prove that what is written in the text is true, or to refute it as false, or to defend it against captious criticisms - these are no part of interpretation, although they are customarily done by pretty well everyone who writes commentaries. There is indeed no reason why an interpreter should not touch lightly on these matters; but a thorough examination of the author's doctrines falls outside the boundary of interpretation. (Translated in Barnes 1992: 271; my emphases)

Such a strict division of labor was absent in earlier periods, and Galen seems to state a minority view. To us, the separation of "a thorough examination of the author's doctrines" and "interpretation" seems contradictory, until we note that it is a matter of degree ("lightly" vs. "thorough"), depending, as Galen sees it, on the particular aim of one's activity. Galen also makes a distinction between intentional misrepresentation of a text (katapseudomenos) and accidental mistakes through ignorance (agnoia).$^{40}$ It is clear that here we have reached a higher level of sophistication, in which a deeper awareness of the requirements and characteristics of the commentator's activity feeds into the execution of the task. The self-monitoring stance about how to proceed, and why, illustrates that exegesis had advanced considerably as a genre which is aware of its own past.

39. See Smith 1996 [1978]: 70, and note, for references. Smith (ibid.: n65) also notes that, as an exercise, Galen reduced twenty anatomical commentaries of Marinus (another teacher) to four books!

40. Galen's On Hippocrates' On the Nature of Man 1.2.25 Kühn (modern ed. CMG vol. 5.9.1 p. 15.13-25) = Theophrastus fr. 231 FHSG. 
Galen's actual procedure has been lucidly clarified recently by Heinrich von Staden (2002), who distinguishes at least four exegetical moves:

1. semantic clarification (ibid.: 112)

2. "expansive inflationary retelling" (ibid.)

3. paraphrasing "Hippocrates" by "Hippocrates" (ibid.: 115)

4. refuting rival interpretations (ibid.: 117).

By themselves, these strategies seem to be reasonable means to the clarification of a text, though a few cautionary comments are in order. Move (1) will make use of parallels, ${ }^{41}$ even from different genres, to elucidate word meanings, in the belief that the ordinary usage of language can also be found in poets. Move (2) is an important development which will become the mainstay of commentary: expansive retelling is a form of paraphrase which allows for unpacking (exhaplôsis), "repackaging," and clarifying in different ways. In addition, Hippocrates' prose is terse and aphoristic. As von Staden (ibid.: 113) rightly stresses, Galen can thus "move from philological interpretation to doctrinal explication," sometimes breaking his own rules. Move (3) is the equivalent of the "Homer from Homer" principle (cf. note 19) and may include "transformative paraphrase" with elisions (ibid.: 116), exposing certain biases and specific interests of the commentator. And move (4) clearly shows that polemic has not lost in importance, not only because medicine was a highly competitive profession but also because Galen was convinced that his predecessors did not live up to his standards in their explication of Hippocrates. Thus, Galen strove for "the recuperative elucidation of the obscure ancient voice" (ibid.: 114) by attempting to design a rigorous and refined methodology of exegesis. He raised the stakes, absorbing existing strategies and extending them.

One final aspect of Galen's method, also brought out by von Staden, needs to be mentioned. Galen has a very broad conception of his activity (much like the anonymous Commentary), which arises from his context and shows in his approach. Von Staden (ibid.: 118, n32) calls this the author's "larger commitments" or "plot" to describe the intention to provide more than just "a sequence of lemmata and comments." This makes the ancient philosophical (and medical) commentary fundamentally different from the modern commentary, which tends to become "molecularized" (ibid.: 121 and 127). ${ }^{42}$ Ancient scientific commentaries were written by practicing

41. I should note that von Staden (ibid.: 111) qualifies the term "parallels" as one of convenience, "under which scholars tend to cluster together quite heterogeneous relations of resemblance."

42. Cf. "atomized" in Gibson 2002: 354 and "morselization" in McCarty 2002: 364 . A further supporting argument is the assumption by many ancient commentators that readers 
scientists and physicians (ibid.: 127): commentary for the sake of commentary was hardly ever an option. I would submit that this holds for the whole tradition as I have been presenting it, in particular the late Platonist commentators from Plotinus onward.

\section{3. (Neo)Platonism}

Many of the emerging reflexes and recurrent themes I have described so far persist in the commentaries of the late Platonists. The idea of "tradition," of placing oneself in a line of interpreters, bestows both authority and continuity upon one's activity. Within the teaching context of the Platonic school, however, a more formalized methodology had been established, and with it came an increasing complexity in the levels of commentary: we should think of the tradition as a complex texture or fabric rather than just accumulated layers (as with Russian dolls). This means we always encounter a complex document, which cannot be read simply as a guide to Aristotle. ${ }^{43}$

The standard topics that crystallized in the later tradition have been studied extensively in recent years. ${ }^{44}$ But there we of course have to do with a well-documented interpretive tradition, which, starting from the first century GE, builds on and reacts to its predecessors as an act of selfproclaimed identity. This allowed for the steady growth and refinement of a set of standard topics which counted as a firm basis for evaluating Aristotle's works. The Neoplatonic commentators came to express these as a fixed set of standard questions for opening the discussion of a text (Mansfeld 1994). Such preliminary questions (e.g., concerning authorship, aim, theme, etc. [see note 54]) would structure the reading of these texts and bear on important issues of authenticity and purpose, which would lay the ground for detailed page-by-page, sometimes line-by-line, commentary. Such an approach, rooted in generations of discussion, required a scholarly environment and the habitual use of books. It also reflects the focus on a body of writings regarded as a fixed authoritative body of knowledge used in teaching, that is, a canon.

It was Syrianus, the Athenian teacher of Proclus (d. $485 \mathrm{CE}$ ), who determined much of the commentary style in the fifth and sixth centuries CE (D’Ancona 2002: 208-11). He adopted Alexander's method of providing

will not pillage the work selectively ("hit-and-run" approach) but read it from start to finish (von Staden 2002: 129, on Hipparchus's commentary to Aratus's Phaenomena).

43. "Evidently, the theological motive of the Neoplatonic curriculum and the pressure to harmonize Plato with Aristotle creates dangers, if the commentaries are read as straightforward guides to Aristotle, without due allowance being made" (Sorabji 1990: 15).

44. E.g., Hadot 1987, 2002b: 167-76; Mansfeld 1994; Blumenthal 1996; Barnes 1997. 
a lêmma (literally, a "snatch" of text) for commenting, and this format became the norm, in preference to several other forms of presentation. ${ }^{45}$ Interestingly, as in earlier periods, the text commented upon is said to use "intentional unclarity": while Orpheus and the poets were said to provide messages in riddles, Aristotle is now said to be deliberately unclear so as to fend off the uninitiated (Ammonius On Aristotle's "Categories" 7.10-11; Busse 1895). This argument for the self-legitimization of the commentator's task (Sluiter 200o) could only lead to expansive supplementation as the main tool for clarification. My next and final case study, Simplicius, illustrates this feature well.

4.3.1. Simplicius of Cilicia: A Case Study In writing his long commentaries, Simplicius (ca. $530 \mathrm{CE}$ ) follows the tradition established by Plotinus, the founder of a new exegetical style which also produced a new philosophy we now call "Neoplatonism." Note, however, that his followers referred to themselves as Platonists (not Neoplatonists, cf. note 34). In line with Plotinus's practice, they came to clarify Aristotle as a prelude to the works of Plato, the real focus of their interest. Simplicius's works serve to illustrate the late commentary style for several reasons: ${ }^{46}$ (a) his commentaries are instructive about the exegetical and didactic practices of the Neoplatonic school, (b) they are highly informative on centuries of Greek philosophy from the Presocratics to his own day, (c) they provide insight into the transition from late antiquity to the Middle Ages, and (d) they show us a particular stage in the interpretation of Aristotle and Plato. Plotinus is described by his followers as a particularly inspired and inspiring teacher who interprets Aristotle and Plato by means of previous interpreters, Alexander of Aphrodisias among them (Porphyry, Life of Plotinus, sec. 14).

Simplicius's scholarly method is thus remarkable and in some ways almost "modern." He is unusually self-conscious of his approach and thoughtful in his assessment of the text, of manuscripts, and of an astounding range of sources (cf. Chase 2003: 8 and below). These scholarly qualities he combines with more practical talents. Since Iamblichus (third century CE), a greater emphasis on religion had resurfaced in philosophy (cf. note 43). It could range from a ritualistic approach (which Proclus calls "theurgy") to theological discussions about theodicy and the creation of the world (Simplicius, Philoponus).

45. For instance, lecture notes ("from the master's voice," apo phônês), or discussion divided into theôria and praxis (Olympiodorus, ca. 650 CE), or interpretive paraphrase (Themistius, ca. $317-387 \mathrm{CE})$.

46. As was most recently pointed out by Chase 2003: 8 . But this has been a growing consensus for some years now; cf. Hadot 1987; Tarán 1987: 246-47 (which mentions two of the four points listed below); de Haas 2001; Baltussen 2002a, forthcoming b. 
The lofty abstractness of the philosophy and interpretation in these works should not mislead us into thinking that Platonism was just an intellectual movement: views were held with strong conviction, and the learning process resembled a religious initiation. In the curriculum, Aristotle's works were treated as the "smaller mysteries" in opposition to Plato's "Greater Mysteries." ${ }^{47}$ Not surprisingly, there are significant parallels with Christian exegetical strategies (Mansfeld 1994), which is at least in part a sign of their common Greek origin. But the rivalry between Christian and pagan positions is even more significant, for both parties strove to win the hearts and minds of men by arguing in books about books, with authoritative texts at the core of their enterprise. During the fourth and fifth centuries, Christianity - the official state religion, supported by real worldly authoritythreatened the pagan schools and ultimately led to the closing of Plato's Academy in Athens in 529 CE.

4.3.2. Simplicius's Use of Alexander of Aphrodisias Simplicius is a prime example of the full-blown commentary style. In his commentary on Aristotle's Categories (7.23-32; Kalbfleisch 1907), Simplicius gives a clear idea of his intentions and aims as a commentator, notably acknowledging debts to earlier exegetes. He also develops a topos of modesty (Barnes 1992: 273), saying that he merely wants to expound Iamblichus's commentary:

The worthy exegete of Aristotle's writings must not fall wholly short of the latter's greatness of intellect (megalonoia). He must also have experience of everything the Philosopher has written, and must be a connoisseur (epistêmôn) of Aristotle's stylistic habits. His judgement must be impartial (adekaston), so that he may neither, out of misplaced zeal, seek to prove something well said to be unsatisfactory, nor, if some point should require attention, should he obstinately persist in trying to demonstrate that [Aristotle] is always and everywhere infallible, as if he had enrolled himself in the Philosopher's school. [The good exegete] must, I believe, not convict the philosophers of discordance by looking only at the letter (lexis) of what [Aristotle] says against Plato; but he must look towards the spirit (nous), and track down the harmony (sumphônia) which reigns between them on the majority of points. (Translated in Chase 2003: 23)

This description of the natural and acquired talents of an exegete (the former also found in Anon. to Theaetetus columns IX-X, Plato Republic V, and Aristotle Nicomachean Ethics $6.1 ; 8 ; 12-13$ ) is still sound today: impartiality (a change from Galen), a broad familiarity with the works and their

47. Mysteries (from the Greek mustês, "initiate") point to the esoteric nature of the process of becoming a Platonist: Aristotle's basic discussion of the components of the world in his Categories was taken as the best introduction to philosophical thought leading up to the grander visions of Plato's metaphysical ideas as read by Plotinus (see Wallis 1972). 
style, and remarkably, a capacity to distinguish between the letter and the spirit of the text. But virtue and hard work are also relevant as well as an interest in learning by frequent and in-depth study of Aristotle's key concepts. Simplicius not only lives up to these criteria but sometimes exceeds them.

His use of his sources further illustrates his skill and innovation in clarifying Aristotle. The weaving of many different voices into the fabric of his commentaries may be compared to the writing of a symphony - an image Simplicius would have liked, since one of his aims is to show that there exists considerable agreement (symphônia) between Plato and Aristotle. To support his argument, he variously uses paraphrase and quotation; about these two devices he even expresses specific views (atypical for the Neoplatonic school), namely, that accurate citation can be more useful than paraphrase (Baltussen 2002a).

Especially remarkable is his use of one particular author, Alexander of Aphrodisias (chair of Aristotelian philosophy in Athens, ca. 200 CE). Among his many references to his preceding commentators, Simplicius mentions Alexander some seven hundred times. ${ }^{48}$ This makes him by far the most-quoted source in Simplicius. Alexander was known in antiquity as "the commentator." ${ }^{99}$ His surviving works show him to be a patient and meticulous thinker and commentator, firmly working within the Aristotelian tradition without agreeing unconditionally with everything Aristotle wrote. $^{50}$

In the references to Alexander in the Physics commentary, however, we immediately face an apparent exception to the rule that Simplicius always used good scholarly methods. He does not introduce Alexander properly (by name and place of birth, as with many others, like Xenophanes of Colophon; 7.3-4: Anaxagoras of Klazomenai $\left.{ }^{51}\right)$. Nor does he name him in a list of his sources, as he does in the context of outlining the task of a commentator (just before the passage quoted above). Alexander, known as

48. This number can only be approximate because it is based on a search on the Thesaurus Linguae Graecae CD-ROM (version D, (c) University of Irvine California) for "Alexand(r)-" and therefore only gives explicit occurrences of the name (and all its cases).

49. See, e.g., Simplicius, Commentary on Aristotle's Physics 80.15-16 and 707.33-34, "most knowledgeable of Aristotle's exegetes."

50. On certain issues, such as on the mortality of the soul, he diverged from Aristotelian orthodoxy (Moraux 1942; Sharples 1987). But for our purposes, it is more important to hold onto his general outlook in his exegetical activities as that of an Aristotelian.

51. On Aristotle's Physics 7.1 Diels 1882. These are incidental references to Presocratics and obviously not exegetical commentaries; on pp. 22-28 (Diels) a significant increase of patronymics occurs, a feature now thought to originate in his source for this section, Theophrastus. 
the Commentator and the most-quoted author in Simplicius's works by far, gets no special mention or introduction at all. The first occurrence of his name is a simple "Alexander" (2.5; Diels 1882), and it is not until the eighteenth occurrence that a further label, relating to the place of provenance, is found ("of Aphrodisias," 19.5; Diels 1882).

What are we to make of this? Some have suggested that the Categories commentary is the most accomplished and complete one. As the starting point of all teaching in the (Neo)Platonic school, the authors would have spent the most time on it ${ }^{52}$-hence the elaborate introduction, the methodological refinement in both stating and executing the overall strategy. By contrast, the Physics commentary would represent a later stage in the curriculum. Because its intended place would be after the Categories, ${ }^{53}$ Simplicius may not have felt the need for special introductions, or he may not have managed to finalize it. ${ }^{54}$ At any rate, given Alexander's prominence as an exegete, it does seem odd that Alexander does not get official "credit" for his role in the commentary; I therefore take this absence as a sign of Simplicius's tacit assumption that Alexander's role here needs no further justification. Note that it is because of the syncretistic strategy of the Platonists that Simplicius can incorporate the views of the Aristotelian Alexander at all. At the same time, since Alexander belongs to his own tradition (Aristotelianism), the act of incorporating him is bound to create tensions (as it did with Galen), and it is here that even Simplicius will admit to disagreement with his illustrious guide - the extent of which has not yet been studied properly.

The passages mentioning Alexander offer a clear opportunity to explore this issue, because their high number constitutes a statistically significant body of evidence; moreover, the majority of them represent direct quotations. As the use of Alexander's works varies, we can distinguish among the following four functions that his work serves in Simplicius (each illustrated by one or two representative examples). ${ }^{55}$

52. See Hadot 1987, Mansfeld 1994.

53. Aristotle had already indicated the sequence in which to conduct the study of nature in his Meteorology A.1 (see Hadot 1987, Algra 1995).

54. The latter option seems unlikely simply because in every other way the introductory pages reflect standard topics of preliminary discussion, such as aim (skopos, 1.1 and 3.13ff.), title (epigraphê, 4.8-16), usefulness (khrêsimos, 4.17ff.), order (taxis, 5.27-31), whether the work is genuine (gnêsios, $5 \cdot 32 \mathrm{ff}$.), etc. For these features as a characteristic of the post-Hellenistic commentary tradition, see Mansfeld 1994 .

55. The categories established here are provisional: they map out broad groups and indicate the diversity with which one individual source was used. One correlation which may produce an especially significant insight is that between length of quotation and (dis)agreement. A fuller discussion is in Baltussen forthcoming c. 
Alexander provides a helpful exegesis of Aristotle. This type of use entails agreement and shows Simplicius looking to his predecessor for enlightenment in understanding or clarifying Aristotle's arguments. Late commentators will not always claim a clarification as their own (a topos), but often the consultation of an authority is genuine (see also next point) and will lead to further discussion of possibilities and textual details. A similar use of clarifications originally made by Aristotle's pupil Eudemus can be found in Simplicius (Baltussen 2002b); and it is of particular interest to note that references to Eudemus and Alexander actually occur close together a considerable number of times, with Alexander building on Eudemus's interpretations. (This forms part of certain source clusters in Simplicius.) Eudemus, called "lover of truth" a number of times (e.g., 1024.6), is often preferred to Alexander.

One passage must suffice to illustrate the typical case. At Commentary on Aristotle's Physics 434.36, the position of Aristotle on physical change is supported by Alexander's comments, which are brought in without qualification: "Now he [Aristotle] wishes to provide clear examples of things reciprocally changed in initiating it [i.e., change] and at the same time, as Alexander says, to separate off the divine body from being reciprocally changed and affected." Such brief interjections ("as Alexander says") are frequent and often signal agreement: a practice that exemplifies the argument from authority which became so common in medieval times.

Alexander is brought in to back up Simplicius's argument and/or to counter the view(s) of others. This type, again based on agreement, resembles an argument from authority in that Alexander's view is invoked for confirmation and/ or is placed in opposition to that of others. ${ }^{56}$ One case of Simplicius countering rival views with the help of Alexander is found at 521.10. Here tôn palaiôn, "thinkers of old," are opposed to the neôteroi, "moderns, upstarts," a contrast already popular in Galen. An exceptional case, somewhere in between the previous two examples, is found at 1358.39-40 against Philoponus. Here Simplicius defends Alexander against an attack by “the Grammarian” (line 39), accusing Philoponus of misunderstanding Alexander:

The Grammarian should have noticed that Alexander did not here investigate how the finite fixed sphere is eternal, but how, being finite, it possesses an infinite power of causing motion. (Translated in McKirahan 2000: 149) ${ }^{57}$

56. For appeal to authority see, e.g., Eudemus fr. 59 with Wehrli's comments, in which Theophrastus is mentioned as having more authority: closeness to the master may indicate higher authority.

57. Additional examples at $582.21 ; 584.4$. Cf. the correction of "his beloved Iamblichus" (Chase 2003: 8, n48), who also misunderstood Alexander. 
In this case, a correct understanding of a text is made the basis for offering clarifications, defending one authority against another. As Jonathan Barnes (1992: 270) tersely comments, "Clarity is a virtue, obscurity a vice." Simplicius's polemic against Philoponus conforms to an established convention of exegesis (Hoffmann 1987). Here the strategy is to portray the opponent as an inferior exegete: he has misunderstood a passage (Alexander's interpretation). Two things stand out: (a) the emphasis on text and its polysemy, and (b) Simplicius now uses a secondary text, making this polemic a tertiary feature, in which previous interpretations become part of the overall discourse of how to understand Aristotle.

Alexander's view is criticized and/or rejected but quoted anyway. In a considerable number of cases, we find Simplicius quoting Alexander with expressed disagreement. ${ }^{58}$ In terms of presentation, he does not seem to have, so to speak, a "principle of economy or concealment," which might have induced him to keep references to views he disagrees with very briefthat is, to quote dismissively and suppress the evidence. Such a procedure would allow a critic to present only as much material as will serve for a convincing refutation of the opponent. Simplicius has been accused of using such an approach unfairly regarding Alexander, on the basis of recently found marginalia of a Paris manuscript, and in this case that verdict seems justified (Rashed 1997) ${ }^{59}$ But other cases show that this assessment should not be generalized: even by modern standards, there is some merit to this practice. It is plausible to ascribe the "redundant" quotations to respect for Alexander's status. One good example of such a quotation is found in $449.6 \mathrm{ff} .{ }^{60}$ It cites several lines from Alexander's text, and then Simplicius squarely contradicts it (449.11-12: "I, however, believe it to be . .."). In another celebrated example, during the debate on the eternity of the world, Simplicius unwittingly preserves parts of Philoponus's Against Aristotle (Wildberg and Furley 1988).

Alexander is quoted or mentioned in connection with a variant in the manuscript tradition. Although this can happen within any of the three categories mentioned above, I have added this as a distinct class of references, because it provides us with detailed information on the scholarly method of Simplicius and the text constitution of Aristotle (see notes 50-51).

In sum, Alexander plays a very important role in Simplicius's commentary, either as authoritative interpreter and guide (second-level authority)

58. There is a notable parallel to this attitude in later commentators of the early Renaissance (Fazzo 1999: 48).

59. These important fragments are from Alexander's lost commentary on Aristotle's Physics.

6o. See also 407.21-28. 
or as a source for ammunition against Simplicius's own rivals. That he is also criticized shows Simplicius to have a mind of his own, despite his heavy reliance on others. Yet most of the time he seems to keep up the pretence (the topos of modesty) of merely passing on wisdom and insight from his predecessors (Sluiter 2000: 200). His use of a rich archive and his scholarly method seem to indicate that his works did not originate in the classroom, even if they may have been intended for it (cf. Praechter 1929).

\section{Toward a History of Ancient Philosophical Commentary}

In this highly selective account, I have argued that exegesis as a generic concept provides a useful starting point for understanding the emergence of philosophical commentary. Even before it became commonplace for philosophers to engage texts in an extensive and detailed manner, we can identify components of interpretation, and these eventually became part of formal commentary (first century BC?). Examination of this evidence allows us to obtain a more complete grasp of the tradition's organic development and push the chronological origins further back, shedding light on the "prehistory" of the exegetical tradition (Grondin 1994). This evolutionary argument focuses on polemic as an important constituent of exegesis, proposing that disagreement can become a litmus test to determine the level of responsiveness and interpretive effort present in polemical argument.

Unclarity in expression or ideas (whether real or imagined) requires clarifying semantic or conceptual shifts. Allegorical exegesis of Homer also shows that changing circumstances might generate attempts at finding "new" meaning in an important text in order for it to remain relevant. But although clarification is always part of the motivation, commentary is rarely an aim in itself: even Homeric allegorizing readings became part of the debate on religion and the new science of nature (see Derveni in Betegh 2005). Thus, "religion, science and the invention of literary criticism were inextricably linked" (Janko 2002-3: 15). From the postclassical era onward, commentary is not merely parasitic upon philosophy, it is philosophy. It is an exercise in understanding the works of the school's founder with the further aim of understanding the world. Authority plays a major role here, and many commentaries simply present their activity as a natural extension of the school founders, with Plato and Aristotle as the prime examples of worthy authorities (Sluiter 2000). Over time, "authorities" multiply in exegesis. But the further we move away from the source, the less likely it is that the original text will be openly challenged.

The growth in sophistication of exegesis was influenced by the increasing 
spread of literacy, which initially prepared the way for linguistic changes, such as the use of the article to signify abstract notions that had been previously expressed in concrete terms (Snell 1953 [1948]: 227-36). In a predominantly oral culture, a fluid and flexible attitude toward the "text" is accompanied by a comparable attitude toward its meaning; a literate culture encourages readers to "fix" or settle the meaning of the written text in a way that is comparable to (and suggested by) the fixity of the text itself, thus increasing the possibility of dispute over the text's meaning and interpretation. ${ }^{61}$ The first clear signs of a clash between the old oral attitude and the new literate one can be found in Plato (Havelock 1963), who expresses deep reservations about written philosophy in the Phaedrus (274b-276a), and in Aristotle, whose literal interpretations of the Presocratics earned him reproach for "distorting" their views. ${ }^{62}$ With hindsight, it is easy to see that Aristotle's interpretation of earlier views is highly context-dependent, but he should be judged against his own aims. Like the Sophists, Plato, and even the Presocratics themselves, Aristotle was part of a dialogical mode of philosophizing at a time when the boundaries and conventions of genre were rather diffuse. His intention is clearly not to distort the views he presents but to understand his predecessors within the framework of his own system of concepts (e.g., Metaphysics 106ga24-25). It was not so much a matter of Aristotle trying to fit the proverbial "square peg into a round hole" as it was an expression of confidence in his own ideas and his lack of interest (and perhaps skill) in producing a historically responsible interpretation of ideas which were quite remote from his own (Cherniss 1935, 1944). Having made certain advances conceptually, he could regard views of the past with a degree of intellectual contempt. His model of epistemological progress (a kind of sociology of science avant la lettre) sees humankind in a cooperative undertaking, moving toward the truth by a joint effort (Metaphysics 98oa21-982a1, 993a3o-b8).

Henceforth, philosophical progress would be determined by a complex set of factors: new work would involve self-consciously embedding one's intellectual activity within a recognized tradition (philosophy) which was understood as a cooperative undertaking geared to finding the truth while exploring the meaning(s) of existing views on the truth. Commenting on others is thereby subordinated to the quest for knowledge and understanding, and the conveying of truths, once they have been established, would involve teaching by way of commentary. Every period would have its "own" Plato or Aristotle, and commentary becomes part of that process of renewal

61. Laws are often written down in the wake of the introduction of script (Hammurabi, ca. 1792-1750 BCE, codifies existing laws) or the Greek alphabet (Draco, 621-620 BCE).

62. E.g., by Cherniss 1944; McDiarmid 1953. 
(Gerson 2005). The label "Neo-Platonism" fails to take this into account, operating with a flawed notion of traditional "purity." In the scientific tradition (e.g., Hipparchus, Galen), commentary embodies a conception of philosophy as a continuous dialogue with the past, intended to correct mistakes and to extract, as von Staden (2002: 115) calls it, "a transepochal scientific 'truth'." In the Platonic tradition, the commentary is a deliberate means to preserve continuity with the past and to pass on an "established" philosophical truth. The syncretistic nature of both strands of the commentary tradition evolved gradually and did not present insurmountable problems (if it was considered at all). An analytical, ahistorical retrospect on this tradition does not produce a proper appreciation of this dynamic process. In this essay, I have tried to capture the dynamic evolution of commentary by tracing the tradition from its preconditions to its mature form.

From "etymology," analogy, and allegory to semantic amplification and doctrinal appropriation, this Protean progression gathered strength and sophistication over the centuries and culminated in the mammoth writings in which first- and second-level authorities vie for attention. The ancient philosophical commentary, formal or nonformal, is thus not so much a deliberate choice of "genre" as a natural by-product of this ongoing dialogue with pupils and colleagues, past and present. The sheer volume of the works arising from it, with their multifarious chorus of voices in multilayered documents of unprecedented length, may surprise us. Yet because these commentaries often have an overarching aim or narrative (a "plot," as von Staden [2002: 118] calls it), which avoids the irksome features of modern commentary, such as fragmentation, parallelomania, the reference-book function (Gibson 2002), many can stand on their own feet as valued and valuable contributions to science and philosophy.

\section{References}

Adamson, Peter, Han Baltussen, and Martin W. F. Stone, eds.

2004 Philosophy, Science, and Exegesis in Greek, Arabic, and Latin Commentaries, 2 vols. Supplement vol. 83 of the Bulletin of the Institute of Classical Studies (London: ICS).

Algra, Keimpe

1995 Concepts of Space in Greek Thought (Leiden: Brill).

2001 "Comments or Commentary? Zeno of Citium and Hesiod's Theogonia," Mnemosyne 54: $562-81$.

Anderson, Graham

1993 The Second Sophistic: A Cultural Phenomenon in the Roman Empire (London: Routledge).

Baltussen, Han

2000 Theophrastus against the Presocratics and Plato: Peripatetic Dialectic in the De sensibus (Leiden: Brill).

2002a "Philology or Philosophy? Simplicius on the Use of Quotations," in Epea and Gram- 
mata: Oral and Written Communication in Ancient Greece, vol. 4, edited by Ian Worthington and John M. Foley, 173-89 (Leiden: Brill).

2002b "Wehrli's Edition of Eudemus of Rhodes: The Physical Fragments in Simplicius On Aristotle's Physics," in Fortenbaugh and Bodnár 2002: 127-56.

2003 "Early Reactions to Plato's Timaeus: Polemic and Exegesis in Theophrastus and

Epicurus," in Ancient Approaches to the 'Timaeus, supplement vol. 78 of the Bulletin of the

Institute of Classical Studies, edited by Robert W. Sharples and Anne Sheppard, 49-71

(London: ICS).

2004 "Plato Protagoras 340-48: Commentary in the Making?" in Adamson et al. 2004, $1: 21-35$.

2006 "Addenda Eudemea," Leeds International Classical Studies 5 (1): 1-28, www.leeds.ac.uk/ classics/lics/2006/2006o1.pdf.

forthcoming a "Galen on the Best Education: How to Read the Right Things in the Right Way," in Purse and Paideia: Receptions of Hellenism in the Second Century AD, edited by N. Livingstone and A. Zadorozhny (Bari, Italy: Levante Editore).

forthcoming b "Simplicius," in Biographical Encyclopaedia of Ancient Natural Scientists, edited by P. Keyser and G. Irby-Massie (London: Routledge).

forthcoming c Philosophy and Exegesis in Simplicius: The Methodology of a Commentator (London: Duckworth).

Barnes, Jonathan

1992 "Metacommentary," Oxford Studies in Ancient Philosophy 10: 267-81.

1997 Logic and the Imperial Stoa (Leiden: Brill).

Bastianini, Guido, and David Sedley, eds.

1995 "Anonymous in Tht. (PBerol. inv. 9782)," in Corpus dei papiri filosofici greci e latini, 3:227-562 (Florence: Olschki).

Bates, Don G., ed.

1995 Knowledge and the Scholarly Medical Traditions (Cambridge: Cambridge University Press).

Betegh, Gábor

2004 "Exegesis in the Derveni Papyrus," in Adamson et al. 2004, 1: 37-50.

2005 The Derveni Papyrus: Cosmology, Theology, and Interpretation (Cambridge: Cambridge University Press).

Blumenthal, Henri J.

1996 Aristotle and Neoplatonism in Late Antiquity: Interpretations of the De Anima (London: Duckworth).

Busse, A., ed.

1895 Ammonii in Aristotelis categorias commentarius (Ammonius' commentary on Aristotle's Categories) (Berlin: G. Reimer).

Califf, David J.

2003 "Metrodorus of Lampsacus and the Problem of Allegory: An Extreme Case?" Arethusa 36: 21-36.

Carson, Anne

1992 "How Not to Read a Poem: Unmixing Simonides from Protagoras," Classical Philology 87 (2): $110-30$.

Chase, Michael, trans.

2003 Simplicius, On Aristotle's "Categories" 1-4 (London: Duckworth).

Cherniss, Harold

1935 Aristotle's Criticism of Presocratic Philosophy (Baltimore, MD: Johns Hopkins Press). 1944 Aristotle's Criticism of Plato and the Academy (Baltimore, MD: Johns Hopkins Press).

1977 "Ancient Forms of Philosophic Discourse," in Harold Cherniss, Selected Papers, edited by

Leonardo Tarán, 14-35 (Leiden: Brill).

D’Ancona, Cristina

2002 "Commenting on Aristotle: From Late Antiquity to the Arab Aristotelianism," in

Geerlings and Schulze 2002: 201-51. 
de Haas, Frans A. J.

2001 "Did Plotinus and Porphyry Disagree on Aristotle's Categories?" Phronesis 46: 492-526.

Diehl, Erich, ed. 1903-6 Procli Diadochi in Platonis Trmaeum commentaria (Commentaries of Proclus the Scholarch on Plato's Trmaeus) (Leipzig: Teubner).

Diels, Hermann, ed. 1882 Simplicii in Aristotelis Physicam Commentaria (Simplicius' Commentary on Aristotle's Physics) (Berlin: G. Reimer).

Dillon, John 1996 [1977] The Middle Platonists: A Study of Platonism, 8o B.C. to A.D. 220, 2nd ed., with a new afterword (London: Duckworth).

Dorandi, Tiziano 1991 "Den Antiken Autoren über die Schulter geschaut: Arbeitsweise und Autographie bei den antiken Schriftstellern," Zeitschrift für Papyrologie und Epigrafik 87: 11-33.

Dover, Kenneth J. 1988 "Thucydides' Historical Judgment: Athens and Sicily," in Greek and the Greeks: Collected Papers. Vol. 2, The Greeks and Their Legacy: Prose Literature, History, Society, Transmission, Influence (Oxford: Blackwell).

Eden, Kathy 1997 Hermeneutics and the Rhetorical Tradition (New Haven, CT: Yale University Press). Fazzo, Silvia 1999 "Philology and Philosophy in the Margin of Early Printed Editions of the Ancient Greek Commentators on Aristotle, with Special Reference to Copies Held in the Biblioteca Nazionale Braidense, Milan," in Philosophy in the Sixteenth and Seventeenth Centuries: Conversations with Aristotle, edited by C. Blackwell and S. Kusukawa, 48-75 (Aldershot, U.K.: Ashgate).

2004 "Aristotelianism as a Commentary Tradition," in Adamson et al. 2004, 1:1-19.

Ferrari, Giovanni R. F.

1984 "Orality and Literacy in the Origin of Philosophy" (discussion of Robb 1983), Ancient Philosophy 4: 195-205.

Fontenrose, Joseph 1978 The Delphic Oracle: Its Responses and Operations, with a Catalogue of Responses (Los Angeles: California University Press).

Ford, Andrew

1994 "Protagoras' Head: Interpreting Philosophic Fragments in Theaetetus," American fournal of Philology 115: 199-218.

Forster, E. S. 1945 "Riddles and Problems from the Greek Anthology," Greece and Rome 14: 42-47.

Fortenbaugh, William W., and István Bodnár, eds. 2002 Eudemus of Rhodes (New Brunswick, NJ, and London: Transaction).

Geerlings, Wilhelm, and Christian Schulze, eds. 2002 Der Kommentar in Antike und Mittelalter: Beiträge zu seiner Erforschung (Leiden: Brill).

Geffcken, Johannes $193^{2}$ "Zur Entstehung und zum Wesen des Griechischen Wissenschaftlichen Kommentars," Hermes 67: 397-412.

Gerson, Lloyd P. 2005 "What Is Platonism?" Fournal of the History of Philosophy 43 (3): 253-76.

Gibson, Roy K.

2002 "'Cf. E.g.': A Typology of 'Parallels' and the Function of Commentaries on Latin Poetry," in Gibson and Shuttleworth Kraus 2002: 331-57.

Gibson, Roy K., and Christina Shuttleworth Kraus, eds. 2002 The Classical Commentary: Histories, Practices, Theory (Leiden: Brill). 
Gottschalk, Hans B.

2002 "Eudemus and the Peripatos," in Fortenbaugh and Bodnár 2002: 25-37.

Grondin, Jean

1994 Introduction to Philosophical Hermeneutics, translated by J. Weinsheimer (New Haven,

CT: Yale University Press).

Hadot, Ilsetraut

1987 Simplicius: Sa vie, son oeuvre, sa survie (Berlin: De Gruyter).

2002a "Der fortlaufende Philosophische Kommentar," in Geerlings and Schulze 2002:

184-99.

$2002 \mathrm{~b}$ "Simplicius or Priscianus? On the Author of the Commentary on Aristotle's De

Anima (CAG XI): A Methodological Study," Mnemosyne 5o (2): 159-99.

Hager, Fritz-Peter 1983 "Zur Geschichte, Problematik, und Bedeutung des Begriffes 'Neuplatonismus'," Diotima 11: 98-110.

Hammond, N. G. L.

1987 "A Papyrus Commentary on Alexander's Balkan Campaign," GRBS 28: 331-47.

Hankinson, Robert James

1991 Galen: On Antecedent Causes (Cambridge: Cambridge University Press).

1998 Galen: On the Therapeutic Method (Cambridge: Cambridge University Press).

Havelock, Eric A.

1963 A Preface to Plato (Cambridge, MA: Harvard University Press).

1982 [1966] "Preliteracy and the Presocratics," in The Literate Revolution in Greece and Its

Cultural Consequences, edited by E. A. Havelock, 220-6o (Princeton, NJ: Princeton Uni-

versity Press).

Hoffmann, Phillip

1987 "Aspects de la polémique de Simplicius contre Philopon," in Hadot 1987: 183-221.

Humphreys, S. C.

1996 "From Riddle to Rigor: Satisfactions of Scientific Prose in Ancient Greece," in Proof and Persuasion: Essays on Authority, Objectivity, and Evidence, edited by S. Marchand and

E. Lunbeck, 3-24 (Turnhout, Belgium: Brepols).

Hussey, Edward

1999 "The Enigmas of Derveni" (Review of Laks and Most 1997), Oxford Studies in Ancient Philosophy 17: 303-24.

Janko, Richard

2002-3 "God, Science, and Socrates," Bulletin of the Institute of Classical Studies 46: 1-18.

Jones, Alexander

1999 "Uses and Users of Astronomical Commentaries in Antiquity," in Most 1999a: $147-72$.

Kahn, Charles

2003 "Writing Philosophy," in Yunis 2003: 139-61.

Kalbfleisch, Christian, ed.

1907 Simplicii in Aristotelis Categorias commentarius (Simplicius' Commentary on Aristotle's Categories) (Berlin: G. Reimer).

Kühn, Carl G.

1821-33 Galenus: Opera Omnia (Leipzig: Teubner) [Reprint 1964-65 Hildesheim:

G. Olms].

Laks, André, and Glenn W. Most, eds.

1997 Studies on the Derveni Papyrus (Oxford: Oxford University Press).

Lamberton, Robert, and John J. Keaney, eds.

1992 Homer's Ancient Readers: The Hermeneutics of Greek Epic's Earliest Readers (Princeton, NJ:

Princeton University Press).

Levinson, Joshua

2004 "Dialogical Reading in the Rabbinic Exegetical Narrative," Poetics Today 25: 497-528. 
Long, Anthony A.

1992 "Stoic Readings of Homer," in Lamberton and Keaney 1992: 41-66.

Mansfeld, Jaap

1986 "Aristotle, Plato, and the Pre-Platonic Doxography and Chronography," in Storiografia e dossografia, edited by G. Cambiano, 1-59 (Turin, Italy: Tirrenia).

1994 Prolegomena: Questions to Be Settled before the Study of an Author or a Text (Leiden: Brill).

McGarty, William

2002 "A Network with a Thousand Entrances: Commentary in an Electronic Age?" in

Gibson and Shuttleworth Kraus 2002: 359-403.

McDiarmid, John B.

1953 "Theophrastus on the Presocratic Causes," Harvard Studies in Classical Philology 61: $85^{-15} 6$.

McKirahan, Richard

2000 Simplicius' Commentary on Aristotle's "Physics" 8.6-10 (London: Duckworth).

McLeod, W. E.

1961 "Oral Bards at Delphi," Transactions of the American Philological Association 92: 317-25.

Moraux, P.

1942 Alexandre d'Aphrodise: Exégète de la Noétique d'Aristote (Liège, Belgium: Faculté de philosophie et lettres; Paris: E. Droz).

Most, Glenn, ed.

1999a Commentaries - Kommentare. Aporematea 4. (Göttingen: Vandenhoeck-Ruprecht).

Most, Glenn

1999b "The Poetics of Early Greek Philosophy," in The Cambridge Companion to Early Greek Philosophy, edited by A. A. Long, 332-62 (Cambridge: Cambridge University Press). 2005 "More on Commentaries" (review of Le Commentaire entre tradition et innovation, edited by M. O. Goulet-Cazé [1999]), Classical Review 55 (1): 169-71.

Nagy, Gregory 1990 Pindar's Homer (Baltimore, MD: Johns Hopkins University Press).

Nehamas, Alexander 1990 "Eristic, Antilogic, Sophistic, Dialectic: Plato's Demarcation of Philosophy from Sophistry," History of Philosophy Quarterly 7: 3-16.

Obbink, Dirk 2003 "Allegory and Exegesis in the Derveni Papyrus: The Origin of Greek Scholarship," in Metaphor, Allegory, and the Classical Tradition: Ancient Thought and Modern Revisions, edited by G. R. Boys-Stones, 177-88 (Oxford: Oxford University Press).

Ong, Walter 1982 Orality and Literacy: The Technologizing of the Word (London: Methuen).

Owen, Gwilym E. L. 1983 "Philosophical Invective," Oxford Studies in Ancient Philosophy 1: 1-25.

Pfeiffer, Richard 1978 [1968] Geschichte der Klassischen Philologie: Von den Anfängen zum Ende des Hellenismus (Munich: Beck'sche Elementarbücher).

Porphyry 1966 Life of Plotinus and the Order of His Books, Ennead I.1-9, translated by A. H. Armstrong (London: Heinemann).

Praechter, Karl 1929 "Simplikios," Realenzyklopaedie der Antike 3A, no. 1 (2nd ser): cols. 204-13.

Rabe, Hugo, ed. 1963 [1899] Philoponus: De aeternitate mundi contra Proclum (On the Eternity of the World against Proclus) (Hildesheim, Germany: G. Olm).

Rashed, Marwan

1997 "A 'New' Text of Alexander on the Soul's Motion," in Aristotle and After, supplement vol. 68 of the Bulletin of the Institute of Classical Studies edited by Richard Sorabji, 181-95 (London: ICS). 
Richardson, Nicholas J.

1975 "Homeric Professors in the Age of the Sophists," Proceedings of the Cambridge Philological Society 21: $65-81$.

1980 "Literary Criticism in the Exegetical Scholia to the Iliad: A Sketch," Classical Quarterly $30(2): 265-87$.

1992 "Aristotle's Reading of Homer and Its Background," in Lamberton and Keaney 1992: $30-40$.

1993 "Aristotle and Hellenistic Scholarship," in La philologie Grecque à l'époque Hellénistique et

Romaine, edited by Nicholas J. Richardson and Franco Montanari, 7-38 (Vandoeuvres-

Genève, Switzerland: Fondation Hardt).

Robb, Kevin, ed.

1983 Language and Thought in Early Greek Philosophy (La Salle, IL: Hegeler Institute).

Rosenberger, Veit

2001 Griechische Orakel: Eine Kulturgeschichte (Stuttgart: Wissenschaftliche Buchgesellschaft).

Runia, David T.

1986 Philo of Alexandria and Plato's "Trmaeus" (Leiden: Brill).

Russo, James

1997 "Prose Genres for the Performance of Traditional Wisdom in Ancient Greece: Proverb, Maxim, Apophthegm," in Poet, Public, and Performance in Ancient Greece, edited by

L. Edmunds and R. W. Wallace, 49-64 (Baltimore, MD: Johns Hopkins University Press).

Schäublin, Christian

1977 "Homerum ex Homero," Museum Helveticum 34: 221-27.

Schmitt, Charles, Quentin Skinner, and Eckhard Kessler, eds.

1988 The Cambridge History of Renaissance Philosophy (Cambridge: Cambridge University Press).

Scodel, Ruth

1986 "Literary Interpretation in Plato's Protagoras," Ancient Philosophy 6: 25-37.

Sedley, David

1997 "Plato's Auctoritas and the Rebirth of the Commentary Tradition," in Philosophia

Togata II: Plato and Aristotle at Rome, edited by Jonathan Barnes and Miriam Griffin, 110-29 (Oxford: Oxford University Press).

1998 Lucretius and the Transformation of Greek Wisdom (Cambridge: Cambridge University Press).

Segal, Charles P.

1962 "Gorgias and the Psychology of the Logos," Harvard Studies in Classical Philology 66:

99-155.

Sharples, R. W.

1987 "Alexander of Aphrodisias: Scholasticism and Innovation," in Aufstieg und Niedergang

der Römischen Welt II.36.2, edited by Wolfgang Haase, 1176-1243 (Berlin: De Gruyter).

Sluiter, Ineke

1995 “The Embarrassment of Imperfection: Galen's Assessment of Hippocrates' Linguis-

tic Merits," Clio Medica 28: 519-53.

1999 "Commentaries and the Didactic Tradition," in Most 1999a: 173-205.

2000 "The Dialectics of Genre: Some Aspects of Secondary Literature and Genre in

Antiquity," in Matrices of Genre: Authors, Canons, and Society, edited by M. Depew and

D. Obbink, 183-203 (Cambridge, MA: Harvard University Press).

Smith, Wesley D.

1996 [1978] The Hippocratic Tradition (Ithaca, NY: Cornell University Press).

Snell, Bruno

1953 [1948] The Discovery of the Mind (New York: Harper).

Sorabji, Richard R. K., ed.

1987 Philoponus and Rejection of Aristotelian Science (Ithaca, NY: Cornell University Press). 
1990 Aristotle Transformed (London: Duckworth).

Tarán, Leonardo 1987 "The Text of Simplicius' Commentary on Aristotle's Physics," in Hadot 1987: $246-66$.

Tarrant, Harold

1993 Thrasyllan Platonism (Ithaca, NY: Cornell University Press).

2000 Plato's First Interpreters (London: Duckworth).

Thomas, Rosalind

1992 Literacy and Orality in Ancient Greece (Cambridge: Cambridge University Press).

van den Berg, Robert M.

2001 Proclus' Hymns: Essays, Translations, Commentary (Leiden: Brill).

von Staden, Heinrich

1995 "Anatomy as Rhetoric: Galen on Dissection and Persuasion," Fournal of the History of Medicine and Allied Sciences 5o (1): 47-66.

1997 "Galen and the 'Second Sophistic'," in Aristotle and After, supplement vol. 68 of the Bulletin of the Institute of Classical Studies, edited by Richard Sorabji, 33-54 (London: ICS).

2002 "'A Woman Does Not Become Ambidextrous': Galen and the Gulture of Scientific

Commentary," in Gibson and Shuttleworth Kraus 2002: 109-39.

Wallis, Richard T.

1972 Neoplatonism (London: Duckworth).

Wardy, Richard

1996 The Birth of Rhetoric: Gorgias, Plato, and Their Successors (London: Routledge).

West, Martin L.

1971 Early Greek Philosophy and the Orient (Oxford: Clarendon).

Whitmarsh, Tim 2005 The Second Sophistic (Oxford: Oxford University Press).

Wildberg, Christian, and David Furley, trans.

1988 Philoponus: Corollaries on Place and Void, translated by David Furley, with Simplicius: Against Philoponus on the Eternity of the World, translated by Christian Wildberg (London: Duckworth).

Wilson, Nigel G.

1969 "Philologia Perennis" (review of Pfeiffer 1968), Classical Review 19: 370-72.

Yunis, Harvey, ed.

2003 Written Texts and the Rise of Literate Culture in Ancient Greece (Cambridge: Cambridge University Press).

Zwierlein, Otto

2002 "'Interpretation' in Antike und Mittelalter," in Geerlings and Schulze 2002: 79-101. 
Copyright of Poetics Today is the property of Duke University Press and its content may not be copied or emailed to multiple sites or posted to a listserv without the copyright holder's express written permission. However, users may print, download, or email articles for individual use. 